\title{
Reversible Streptamer Technology Facilitates the Selection of T Regulatory Cells From Cryopreserved Cord Blood
}

Richard Duggleby ( $\sim$ Richard.Duggleby@anthonynolan.org )

Anthony Nolan Research Institute: Anthony Nolan https://orcid.org/0000-0002-4263-9887

Divya K. Shah

Anthony Nolan Research Institute: Anthony Nolan

Kathryn E. Strange

Anthony Nolan Research Institute: Anthony Nolan

Hoi Pat Tsang

NHS BT: NHS Blood and Transplant

Christian Stemberger

Juno Therapeutics

Lothar Germeroth

Juno Therapeutics

\section{Stephan Mielke}

Universitätsklinikum Würzburg: Universitatsklinikum Wurzburg

Halvard Bonig

Goethe-Universität Frankfurt am Main: Goethe-Universitat Frankfurt am Main

Hermann Einsele

Universitätsklinikum Würzburg: Universitatsklinikum Wurzburg

David Roberts

NHS BT: NHS Blood and Transplant

\section{Sergio Querol}

OCATT: Organitzacio Catalana de Trasplantaments

\section{Alejandro Madrigal}

Anthony Nolan Research Institute: Anthony Nolan

\section{Aurore Saudemont}

Anthony Nolan Research Institute: Anthony Nolan

\section{Diana Hernandez}

Anthony Nolan Research Institute: Anthony Nolan

\section{Robert Danby}

Anthony Nolan Research Institute: Anthony Nolan 


\section{Research Article}

Keywords: T regulatory cells, Streptamer isolation, umbilical cord blood, GMP

Posted Date: March 2nd, 2022

DOI: https://doi.org/10.21203/rs.3.rs-1295146/v1

License: (c) (i) This work is licensed under a Creative Commons Attribution 4.0 International License. Read Full License 


\section{Abstract}

Background: Allogeneic haematopoietic stem cell transplantation (HCT) is a curative option for haematopoietic diseases. However, a major limitation to the success of HCT is graft-versus-host disease (GvHD). The use of T regulatory cells (Tregs) as prophylaxis or treatment for GvHD has now emerged with a number of active clinical trials. Whilst many studies use Tregs from the original HCT donor, the future of this cell therapy could be third-party Tregs. Cord Blood (CB), with its established banks, represents a potential source of third-party cells. However, isolating a high purity Treg cells from cryopreserved CB is difficult without employing flow sorting. Here we investigated the feasibility of using reversible streptamer technology-based selections to obtain clinical grade Tregs from cryopreserved CB units.

Results: A streptamer-based Treg selection was developed with both single-step, CD25 only positive cell selection and two-step, CD4 then CD25 positive selection from cryopreserved CB units, to yield a method that can be readily adapted to full good manufacturing practice (GMP). The best purity was achieved with a two-step streptamer isolation method, giving median purities of $89 \%$ Tregs of total cells. This method took advantage of the reversible nature of the streptamer technology allowing for successive positive selections for $\mathrm{CD} 4^{+}$and then $\mathrm{CD} 25^{+}$cells from cryopreserved $\mathrm{CB}$ units in an enclosed bag system. Isolated Tregs subsequently demonstrated 300 -fold culture expansion using anti-CD3/28 beads. The expanded cells contained high proportions of cells with a Treg phenotype (both by flow cytometry and epigenetics) and demonstrated suppressive function.

Conclusions: Using streptamer selection, highly enriched Tregs could be isolated from cryopreserved CB. The method could be performed in an enclosed bag system utilizing readily available clinical processing materials. Moreover, Tregs selected in this manner could be expanded in culture to make a clinically relevant dose from a cryopreserved CB unit. Thus, streptamers represent a viable alternative to column based magnetic bead or fluorescent activated cell sorting (FACS)-based methods for selection of clinical grade Tregs from banked CB units.

\section{Background}

Allogeneic haematopoietic cell transplantation (HCT) is a curative therapy for serious haematological disorders, including acute leukaemia. To date though, allogeneic HCT is still associated with significant risk of post-transplant morbidity and mortality [1], with one of the main transplant complications being graft-versus-host disease (GvHD); a condition where donor T cells (graft) react against recipient (host) cells due to immunological disparities between donor and recipient [2]. The current mainstay for the prevention and treatment of GvHD is pharmacological immunosuppression but many of the drugs used have unwanted side-effects (reviewed in [1]). Cellular therapy, using T regulatory cells (Tregs), offers an attractive alternative and has been shown, in animal models, to suppress GvHD without impacting on the beneficial graft-versus-tumour (GvT) response following HCT [3-7]. Consequently, there are several clinical trials (17 on record, 5 in phase II, 7 trials with expanded/manipulated Tregs) completed, or 
ongoing, involving the use of Treg therapy for GvHD in the context of HCT (reviewed by [8] and [9]). These trials have demonstrated that Tregs are well tolerated and efficacious in reducing GvHD, at least when used prophylactically $[8,9]$.

In the majority of clinical trials utilizing Treg therapy in HCT, the Tregs were isolated from the original HCT donor [8, 9]. However, a potentially attractive strategy is to use cells from a third-party donor. Third-party Tregs can be isolated and expanded in batches, with manufacturing risks and costs being distributed across batches (as reviewed by MacDonald et al. [9]). Additionally, as third-party cells can be produced in advance, extensive quality control of the cell product is possible whilst making the cells available for immediate "off-the-shelf" use. To date, clinical trials of third-party Tregs have been limited to CB Tregs and CB HCT [8-10]. As a source of third-party Tregs, CB can be readily obtained from established, clinically accredited, cord blood banks. CB Tregs are predominantly CD45RA ${ }^{+}$, indicating that they are a naïve or resting Treg population [11-14]. Evidence from both animal and human models suggest that naïve/resting Tregs exhibit increased phenotypic and epigenetic stability compared with memory Tregs $[15,16]$. Finally, both Brunstein et al. and Seay et al. have also demonstrated that Tregs isolated from CB can be expanded several fold higher than adult peripheral blood Treg cells $[10,17]$.

For clinical application, Tregs are generally enriched from whole blood, predominately through CD25 positive cell selection (reviewed [8]). The current selection strategies conforming to good manufacturing practice (GMP) are magnetic bead based; isolation of Tregs is achieved by positive selection with antiCD25 antibody-microbead conjugates, with depletion of CD25 expressing non-Treg cells using anti-CD8 and/or anti-CD19 antibody-bead conjugates [18-20]. Additional negative cell selections are, however, prevented by the prohibitive costs of the clinical grade antibody-conjugates, limiting Treg purity when isolating Tregs from fresh peripheral blood (PB), and mobilized peripheral blood stem cell sources [1822]. Due to these purity issues, clinical grade FACS based isolation methods are being developed [8], but are as yet, not readily available.

The aim in this study was to determine the feasibility of using a streptamer-based method for the isolation of Tregs from cryopreserved CB units in order to produce GMP compliant products for cellular therapy. In streptamer based selections, the selecting moiety is a Fab antibody fragment complexed with a Strep-Tactin-microbead core. The complex can be dissociated in the presence of biotin allowing for the separation of the reagent from the isolated product. This permits multiple sequential positive selections and the reagents themselves are not retained in the final product, thus reducing the presence of excipients [23]. Additionally, Streptamer based technologies can be used to isolate cells from whole blood which avoids the difficulties that arise in mononuclear cell separation of cryopreserved CB. In this study, we report on the use of a streptamer-based selection strategy to obtain high purity Tregs from cryopreserved $\mathrm{CB}$ units. Further, we assessed their ability to expand and retain a Treg phenotype and function post expansion and compare them to previously published studies of Tregs isolated using conventional methods $[10,17,24]$. Together these factors suggest that streptamers represent a viable and attractive alternative to magnetic bead selection for the isolation of rare cell populations from cryopreserved whole blood. 


\section{Results}

\section{Isolation of Tregs from cryopreserved CB}

Treg cells were selected from cryopreserved CB using either a single-step, anti-CD25-streptamer selection or a two-step, anti-CD4 followed by an anti-CD25-streptamer selection. The isolated cells were assessed by flow cytometry (using the panels shown in supplementary S1 Table). With the single-step selection, only $41 \%$ (range, $30-59$ ) of the live $C D 45^{+}$cells (leukocytes) isolated had the desired $C D 4^{+} C D 25^{+} \operatorname{CD} 127^{\text {low }}$ phenotype (Table 1). However, the proportion of $\mathrm{CD} 25^{+} \mathrm{CD} 127^{\text {low }}$ cells within the CD4+ population was high [median 93\% (89-94)], indicating that the majority of impurities were CD4- cells. This was solved by taking advantage of the reversible nature of the streptamer technology and using a two-step sequential selection method (anti-CD4 selection first, followed by anti-CD25). With the two-step selection, the purity of the $\mathrm{CD} 4^{+} \mathrm{CD} 25^{+} \mathrm{CD} 127^{\text {low }}$ cells was increased to $89 \%$ (63-92) of the live CD $45^{+}$cells (Table 1 ). The purity (proportion of $\mathrm{CD} 25^{+} \mathrm{CD} 127^{\text {low }}$ ) within the live $\mathrm{CD} 4^{+}$population was comparable to single-step selections at 91\% (86-95) (Table 1). In both cases, separate intranuclear staining indicated that the majority of the $\mathrm{CD} 4^{+} \mathrm{CD} 25^{+} \mathrm{CD} 127^{\text {low }}$ population was also FOXP3 ${ }^{+}[99.4 \%(99.2-99.6)$ and 99.7 (96.9-100) for single and two-step selections, respectively; Table 1].

Table 1

efficiency, yield, and purity of streptamer selections

\begin{tabular}{|c|c|c|c|c|c|c|}
\hline & $\begin{array}{l}\% \mathrm{CD}^{+} \mathrm{CD} 4^{+} \mathrm{CD} 25^{+} \\
\text {CD127 } 127^{\text {low }} \text { of } \mathrm{CD} 45^{+}\end{array}$ & $\begin{array}{l}\% \mathrm{CD} 4^{+} \mathrm{CD} 25^{+} \\
\mathrm{CD} 127^{\mathrm{low}} \text { of } \mathrm{CD} 4^{+}\end{array}$ & $\begin{array}{l}\text { \%FOXP3 }{ }^{\text {hi }} \text { of } \\
\text { CD } 4^{+} C D 25^{+} C D 127^{\text {low }}\end{array}$ & $\begin{array}{l}\% \\
\text { eff }\end{array}$ & $\%$ yield & $\mathbf{n}$ \\
\hline $\begin{array}{l}\text { Single- } \\
\text { step* }^{*}\end{array}$ & $41(30-59)$ & $93(89-94)$ & $99.4(99.2-99.6)$ & $\begin{array}{l}6 \\
(3- \\
6)\end{array}$ & $\begin{array}{l}0.04 \\
(0.03- \\
0.06)\end{array}$ & 3 \\
\hline $\begin{array}{l}\text { Two- } \\
\text { step }^{\dagger}\end{array}$ & $89(63-92)$ & $91(86-95)$ & 99.7(96.9-100.0) & $\begin{array}{l}5 \\
(1- \\
9)\end{array}$ & $\begin{array}{l}0.04 \\
(0.01- \\
0.09)\end{array}$ & 8 \\
\hline \multicolumn{7}{|c|}{ * CD25 only selection } \\
\hline \multicolumn{7}{|c|}{ t CD4 and CD25 selection } \\
\hline \multicolumn{7}{|c|}{$\begin{array}{l}\% E f f=\text { (number of live } C D 3^{+} C D 4^{+} C D 25^{+} C D 127^{\text {low }} \text { cells in isolated cell fraction/ number of live } \\
C D 3^{+} C D 4^{+} C D 25^{+} C D 127^{\text {low }} \text { cells in starting } C B \text { unit) } \times 100\end{array}$} \\
\hline \multicolumn{7}{|c|}{$\%$ Yield $=$ (number of cells isolated/starting TNC) $\times 100$} \\
\hline
\end{tabular}

Despite the added step in the two-step selection, the proportion of Treg recovered from each CB unit (efficiency) with the two selection methods were similar. The single-step selection recovered 6\% (3-6) of the live $\mathrm{CD} 4^{+} \mathrm{CD} 25^{+} \mathrm{CD} 127^{\text {low }}$ cells present in the original $\mathrm{CB}$ unit (Table 1) whilst the two-step method 
recovered 5\% (1-9) (Table 1). Cellular yields, that is the number of $C D 4^{+} \mathrm{CD} 25^{+} \mathrm{CD} 127^{\text {low }}$ cells isolated as a proportion of the TNC count of the starting CB unit, were also very similar, being $0.04 \%(0.03-0.06)$ and $0.04 \%(0.01-0.09)$ for the one and two step methods, respectively (Table 1). Given the cell yields for the two-step selection, we anticipate Treg selections from a standard clinical CB unit of between 1.5-2.5 $\times 10^{9}$ TNC to yield between $0.6-1.0 \times 10^{6}$ live $C D 4^{+} C D 25^{+} C D 127^{\text {low }}$ cells. Since clinical trials of Treg therapies have reported using cell doses of between $35 \times 10^{6}-280 \times 10^{6}$ cells [8], our expected cell yield is unlikely to be sufficient for clinical application. Consequently, we investigated the feasibility of expanding the streptamer selected cells ex-vivo.

\section{Expansion of streptamer selected cells}

\section{i) Capacity of streptamer selected Tregs to expand ex-vivo}

Cells isolated using the two-step streptamer selection method expanded, in ex-vivo culture (with anti$\mathrm{CD} 3 / 28$ beads), with a peak rate of $9.3 \pm 3.4$-fold increase in total cells per week when stimulated with anti-CD3/28 beads in the presence of IL-2 (Fig. 1A). After three weeks the average cumulative expansion was 294 -fold \pm 179 (Fig. 1B). With a calculated cell yield from the two-step selection method of between $0.6-1.0 \times 10^{6}$ cells/cord, we can estimate that 3 weeks of expansion should yield between $1.8-2.9 \times 10^{8}$ cells/cord.

\section{ii) Characterisation of expanded streptamer selected cells}

The surface and intranuclear markers used to identify Tregs in the resting cell populations such as CD25, CD127, and FOXP3 are affected by the activation status of the cells caused by the culture conditions. To account for this, the expanded cells were characterised by a more extensive flow cytometry antibody panel to distinguish between activated effectors and true Tregs (S2 Table). The proportions of CD3+CD4+ cells within the live CD45+ compartment is similarly high in both the Treg and CD $4^{+} \mathrm{CD} 25^{-}$derived effector cell cultures, as expected (median 99.2\% (range 75.2-99.9) and 98.8\% (96.5-99.8), respectively; Fig. 2B and SUP Fig. 1). In the expanded Tregs, most of the CD $3^{+} C D 4^{+}$cells $(97.7 \%(66.8-99.3))$ are also $\mathrm{CD} 25^{+}$, and $96.3 \%$ (65.4-98.5) of them display the core Treg phenotype

$\mathrm{CD}^{+} \mathrm{CD} 4^{+} \mathrm{CD} 25^{+} \mathrm{CD} 127^{\text {low }} \mathrm{FOXP} 3^{\text {hi }}$. This is true for the effector cultures too. However, there was clearly differential expression of the markers CXCR4, Helios, CD62L, and CCR7 in Treg cultures compared to effector T cell cultures (Fig. 2A). All four markers are expressed in a higher proportion of the core Treg phenotype cells in the Treg cultures compared to the effector cultures (SUP Fig. 1). In the expanded Treg cultures, cells with the core phenotpye (CD3 $\left.{ }^{+} \mathrm{CD} 4^{+} \mathrm{CD} 25^{+} \mathrm{CD} 127^{\text {low }} \mathrm{FOXP} 3^{\text {hi }}\right)$ and also Helios ${ }^{\text {hi }}$ expression accounted for $86.1 \%$ (73.6-95.8) of the live $\mathrm{CD} 45^{+}$cells (Fig. 2B). Core phenotype and CXCR4 ${ }^{+}$cells made up $76.4 \%$ (61.1-93.7) of the live CD $45^{+}$cells, whilst core phenotype and CD62L ${ }^{\text {hi }}$ CCR $7{ }^{\text {hi }}$ expressing cells were $58.8 \%$ (39.4-73.0) of the cells present (Fig. 2B). This was not the case in effector cultures; whilst core phenotype expressing cells were median 70.6\% (53.2-93.1) of the $\mathrm{CD} 45^{+}$cells, those cells also expressing Helios ${ }^{+}$and CXCR4 ${ }^{+}$were only $19.2 \%$ (2.9-32.3), and $15.2 \%$ (4.9-45.9), respectively (SUP 
Fig. 1). Core phenotype and $C D 62 L^{\text {hi }} C C R 7^{\text {hi }}$ expressing cells in the effector cultures were $29.2 \%(13.0-$ $37.8 \%$ ) of $\mathrm{CD} 45^{+}$cells (SUP Fig. 1 ).

\section{iii) DNA-based enumeration of natural Treg cells}

In the representative data shown in Fig. 2A, after 3 weeks of expansion, $>90 \%$ of the $\mathrm{CD}^{+} \mathrm{CD} 4^{+} \mathrm{CD} 25^{+} \mathrm{CD} 127^{\text {low }}$ cells express $\mathrm{FOXP}^{+}$. This is also true in the paired effector $\mathrm{T}$ cell fraction where FOXP3 is induced by activation. Thus, to confirm that the expanded Treg cultures contained high proportions of natural/thymic Tregs, we analysed the methylation status of the TSDR of FOXP3 gene, as this remains unchanged by induction of FOXP3 expression [25]. The number of Treg and non-Treg cells present in the original cultures can be calculated from the number of copies of the demethylated and methylated TSDR that are detected by qPCR (Fig. 3). Using DNA extracted from expanded Treg cultures we calculated that on average $64 \% \pm 4$ (median $63 \%, n=4$ ) of the of the cells contained a demethylated FOXP3 TSDR (Fig. 3). In contrast, this pattern was only seen in $1 \% \pm 0.5$ (median $1 \%$ ) of the cells in the effector T cell cultures (Fig. 3). This confirms that the selected and subsequently expanded Treg cells were indeed natural/thymic Tregs. It should be noted that the cultures assessed in Fig. 3 were derived from female CB units. Since the FOXP3 gene is located on the X-chromosome, the values shown reflect allowance for the extra (inactive) copies of methylated TSDR present in each cell.

\section{iv) Function of expanded Tregs}

Expanded Treg cultures demonstrated suppressive function at all the ratios of Tregs to target adult CD $4^{+}$ cells tested (Fig. 4). Maximum suppressive activity was seen at the highest Treg to target $\mathrm{CD} 4^{+}$cells tested (two Tregs to one target cell) with a median percentage suppression of proliferation of target CD $4^{+}$ cells of $69 \%$ (range 46-75). The amount of suppression observed was dose dependent but significant suppressive activity was still detected even at a ratio of one Treg to four target cells (41\% (24-56)). By comparison, expanded effector $\mathrm{T}$ cell cultures (from the $\mathrm{CD} 4^{+} \mathrm{CD} 25^{-}$fraction), showed limited and inconsistent suppression of target $\mathrm{CD} 4^{+}$cell proliferation at the highest ratio of two effector $\mathrm{T}$ cells to one target cell (Fig. 4; $24 \%(-72-45)$ ). At the lower ratio, of one effector $T$ cell to four target $T$ cells, no suppressive activity was evident (Fig. 4; -10\% (-86-19).

\section{v) Additional phenotypic characteristics of expanded streptamer selected Tregs}

Having established the purity and function of the expanded streptamer selected Tregs, additional assays were used to determine if the cells were showing indicators of cellular exhaustion (Fig. 5A), or loss of function (in vivo) (Fig. 5B) and which chemokine receptor profile they expressed (Fig. 5C). After three weeks in culture the expression of exhaustion markers was low, with only $2.17 \%(0.02-15.46)$ of the core phenotype expressing cells ( $\left.C D 3^{+} \mathrm{CD} 4^{+} \mathrm{CD} 25^{+} \mathrm{CD} 127^{\text {low }} \mathrm{FOXP} 3^{\text {hi }}\right)$ also expressing $2 \mathrm{~B} 4,0.76 \%(0.20-42.15)$ PD-1, and 3.1\% (0.81-12.51) CXCR3 (Fig. 5A). 
Brunstein et al. screened their expanded Tregs for the presence of OX40 and 41BB expression, as these surface markers have been associated with loss of function, and for downregulation of CD62L expression, indicating a loss of the naïve Treg phenotype[24]. In our expansion cultures from streptamer selected Tregs, the median proportion of $\mathrm{CD} 4^{+} \mathrm{CD} 127^{\text {low }} \mathrm{Helios}^{\text {hi }} \mathrm{FOXP} 3^{\text {hi }}$ cells expressing OX40 was $6.8 \%$ (3.1-11.3), 4.8\% (2.2-8.6) expressed 41BB, and 99.9\% (99.7-100) of the cells were CD62L ${ }^{+}$(Fig. 5B). Thus, the cells have not lost their function during culture and retain a naïve $T$ cell phenotype.

Next the expanded streptamer selected Tregs were characterised for their chemokine receptor profile (Fig. 5C). Based on the expression of the chemokines CXCR3, CCR4, CCR6 and CCR10, Tregs can be defined as Th1-like $\left(\mathrm{CXCR}^{+}\right)$, Th2-like $\left(\mathrm{CXCR}^{-}{ }^{-} \mathrm{CCR}^{-}{ }^{-}\right)$, Th17-like $\left(\mathrm{CXCR}^{-}{ }^{-} \mathrm{CCR} 4^{+} \mathrm{CCR}^{+}{ }^{+} \mathrm{CCR} 10^{-}\right)$or Th22like $\left(\mathrm{CXCR} 3^{-} \mathrm{CCR} 4^{+} \mathrm{CCR} 6^{+} \mathrm{CCR} 10^{+}\right)$. Previous reports suggested that cultured $\mathrm{CB}$ Tregs have predominantly a Th2-like chemokine receptor phenotype [24]. In our cultures, a high proportion (61.6\%

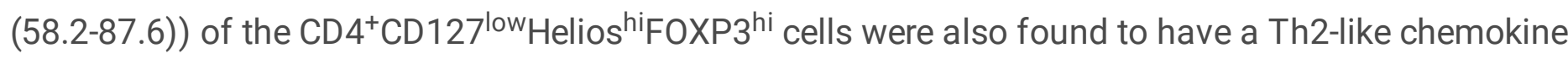
receptor profile. Of the remaining $\mathrm{CD} 4^{+} \mathrm{CD} 127^{\text {low }_{\text {Helios }}}{ }^{\text {hi}} \mathrm{FOXP3}{ }^{\text {hi }}$ cells, 9.6\% (0.3-16.5) had a Th1-like phenotype, 23.0\% (11.5-29.7) a Th17-like, and 1.3\% (0.2-2.3) a Th22-like (Fig. 5C).

\section{Discussion}

The aim in this study was to determine the feasibility of using a streptamer-based method for the isolation of Tregs from cryopreserved CB units in order to produce GMP compliant products for cellular therapy. Here the basis of the selection was streptamer technology with the only previously reported streptamer based isolation of Tregs being on fresh adult peripheral blood [23]. Ideally, a single-step selection method would have been employed, using only anti-CD25 streptamers. The selections could have been achieved in fewer steps, using less reagents, and with minimal time in a clean room facility. However, whilst the majority of selected $\mathrm{CD} 4^{+}$cells were $\mathrm{CD} 4^{+} \mathrm{CD} 25^{+} \mathrm{CD} 127^{\text {low }}$ and FOXP3 ${ }^{\text {hi }}$ (Treg phenotype in fresh adult and $C B$ [26]), over half of all cells present in the isolated $C D 25^{+}$fraction were $\mathrm{CD}^{-}{ }^{-}$contaminants. For safety reasons, a higher purity clinical product is needed and to achieve this we took advantage of the reversible nature the streptamer technology; unlike the majority of contemporary selection methods, that are antibody-nanobead based [18-20], streptamers can be dissociated away from the cells after selection to allow for multiple positive selection steps. Using streptamers to select for $\mathrm{CD} 4^{+}$cells and then $\mathrm{CD} 25^{+}$cells from cryopreserved $\mathrm{CB}$ units and with an enclosed selection procedure, a final Treg population with notably better purity to that of one step-selections (median $89 \%$ of live CD $45^{+}$ cells were Tregs) was achieved. This level of purity compares favourably to other clinical CB Treg selections, such as those described by Brunstein et al., using CliniMACS based selections (median 65\% purity)[10]. Although, higher purities have been reported with FACS sorting (median 97\%)[17], this technique possess difficulties for clinical manufacturing. Additionally, by using positive selection exclusively, only clinical grade anti-CD4 and anti-CD25-streptamers were required; for negative selection methods, clinical grade selecting moieties for all the unwanted cell types would be required. 
The median live Treg cell yield from these CB selections was $0.04 \%$ of the starting TNC. From this, a cell yield of $0.6-1.0 \times 10^{6}$ live Treg cells can be estimated from a standard clinical grade CB unit of $1.5-2.5 \times 10^{9}$ TNC. The $\%$ efficiency of selection was $5 \%$ of the live Tregs in the starting material. In comparison, using the cell yields described in Brunstein et al's. study, using the CliniMACS system with CB units [10], the median efficiency of selection was $27 \%$ (calculated from their reported cell yields). Whilst this is obviously higher, in their selections, the median purity of selected cells was only $65 \%$. Therefore, a higher efficiency might be possible, but at the cost of reduced purity.

Typical Treg cell doses used in clinical trials in the HCT setting are between $0.5-4 \times 10^{6} \mathrm{cell} / \mathrm{kg}$ ([8]) (35$280 \times 10^{6}$ total Treg cells). Therefore, it was clear that the streptamer isolated cells ability to expand would also need to be assessed. Using an anti-CD3/28 bead method, based on Brunstein's et al. first clinical study [10], resulted in maximum rate of expansion of 10-fold/week, to give a cumulative expansion of 290 -fold \pm 180 after 3 weeks of culture. This rate of expansion is comparable to Brunstein's et a/ 2011 study [10] indicating that the streptamer isolation method has not compromised the ability of the $\mathrm{CB}$ Tregs to expand. With this level of expansion, we estimate that Treg doses of $2.6-4.3 \times 10^{6} / \mathrm{kg}$ (based on an average adult weight of $70 \mathrm{~kg})$ could be produced from clinical CB units (1.5-2.5 $\left.\times 10^{9} \mathrm{TNC}\right)$. Brunstein et al. later used a transgenic K562 cell line based expansion method for their 2016 study, and achieved higher doses, but cell line based expansion is not clinically approved in the UK or Europe at this time [24].

Following expansion, the proportions of $\mathrm{CD}^{+}$and $\mathrm{CD} 3^{+} \mathrm{CD} 4^{+}$cells present in the expanded Treg cultures were high, indicating that the expansion conditions did not favour the growth of any contaminating $\mathrm{CD}^{+}{ }^{+} \mathrm{CD} 4^{-}\left(\mathrm{CD} 8^{+}\right)$cells. The proportions of cells with the core Treg phenotype of $\mathrm{CD}^{+} \mathrm{CD} 4^{+} \mathrm{CD} 25^{+} \mathrm{CD} 127^{\text {low }} \mathrm{FOXP}{ }^{\text {hi }}$ were also high (96\%). However, due to the activated state of the expanded Treg cultures, markers that are sufficient to identify Tregs immediately post isolation are no longer specific to Tregs, as CD25, CD127 and FOXP3 are upregulated in all T cells upon activation (reviewed[27]). As such, similar proportions of these cells were also seen in parallel expansions of CD ${ }^{+}$CD $25^{-}$derived, effector T cells (Fig. $2 \mathrm{~A}$ and SUP Fig. 1). In more recent studies, Brunstein et al. included the additional marker Helios, associated with thymically derived Tregs [24, 28]. Since a high proportion of CB Tregs are thought to be recent thymic emigrants [29], this is likely to be more specific for CB Tregs. In our study we also assessed for the expression of CXCR4, as this chemokine receptor is implicated in retaining Tregs in bone marrow [30] and is also associated with CB Tregs [31]. In both cases core Treg phenotype positive cells that were also Helios ${ }^{\text {hi }}$ or $\mathrm{CXCR} 4^{+}$were present in high proportion in the in the expanded Treg cultures, whilst being much lower in parallel effector T cell cultures (Fig. 2B and SUP Fig. 1). With both of these markers being likely indicative of CB Tregs, suggesting that, at least by flow cytometry, the expanded streptamer isolated Treg cultures retained high proportions of Tregs. The proportions of Tregs present after expansion are also comparable to previously described CB Treg expansions of conventionally isolated cells $[10,24]$.

Further confirmation of the identity of the expand Treg cultures was achieved through epigenetic characterisation and functional assessment. We have previously confirmed that the demethylated FOXP3 
TSDR content by qPCR correlates with the resting Treg content in CB units [32]. Such epigenetic enumerations of the TSDR [33] are ideal for assessing expanded Treg cultures as they are not affected by activation status of the cells; induction of FOXP3, as opposed to constitutive expression in Tregs, does not lead to demethylation of this region of the FOXP3 gene in activated T cells [25]. Our Treg cultures contained high proportions of cells with demethylated FOXP3 TSDR, although It should be noted that the proportion of Tregs cells calculated based on the proportions of demethylated FOXP3 TSDR was not as high as the proportion of Helios $^{+}$core phenotype ${ }^{+}$cells, by flow cytometry (median $86 \%$ vs $63 \%$ ). The proportion of Treg observed using TSDR was, notably, similar to that of CD62L hi CCR7 hi cells with the core phenotype (59\%). This might indicate that the true Treg population is a subset of that defined by flow cytometry. However, we should also be cautious interpreting these observations, as our previous study indicated that these assays are not completely equivalent [32]. Therefore, this may simply be an artefact of using different assessment methods to enumerate the Tregs. Other groups, expanding CB Tregs obtained using FACS, have observed higher proportions of demethylated FOXP3 TSDR following expansion, with some variability depending on the expansion protocol used [17]. It is possible, therefore, that the proportion of demethylated FOXP3 TSDR post-expansion might be improved by altering the expansion method. Overall, the high proportion of demethylated FOXP3 TSDR we observe is indicative of the Treg population being maintained in our expansion cultures with little outgrowth of contaminating non-Tregs. Consistent with this is also the high levels of suppression observed by cultured Tregs of adult target $T$ cells. Suppression was observed at all ratios of Tregs to target cells tested, including at a 1:4 Tregs to target cells. In these assays, expanded effector cells (from the same isolations) were used as controls at the maximum and minimum number of expanded cells to target cells present. At a ratio of 2:1 effector cells to target cells, some inhibition of proliferation is observed, likely due to competition for nutrients with the target cells $\left(0.16 \times 10^{6}\right.$ total cells/well). At 1:4 effectors to target cells $\left(0.125 \times 10^{6}\right.$ total cells/well), target cell proliferation was unaffected by the presence of expanded effector cells. This indicates that only the expanded Tregs were demonstrating true suppressive activity; being suppressive even at low Treg to target cell ratios where competition for nutrients is unlikely to be affecting the target cell proliferation. The levels of suppressive activity observed with the expanded Tregs were comparable to other studies of expanded CB Tregs, suggesting comparable functional attributes [17].

Having demonstrated that the expanded streptamer selected Treg cultures contained high proportions of thymic Tregs by flow cytometry, epigenetics and suppressive activity, further characterisation was performed to allow for comparison with other clinical grade CB Treg expansions. The expanded Tregs were assessed for exhaustion markers since Treg exhaustion may limit further in vivo expansion and/or clinical activity after infusion into patients. Core phenotype cells showed no signs of cellular exhaustion by flow cytometry with low proportions of $2 \mathrm{~B} 4^{+}$and PD $-1^{+}$cells being present ([34] and reviewed[35]). Extended phenotyping of the expanded Tregs involved characterisation for functional marker expression and chemokine receptor expression. These were performed on the $\mathrm{CD} 4^{+} \mathrm{CD} 127^{\text {low }} \mathrm{Helios}^{\text {hi }} \mathrm{FOXP} 3^{\text {hi }}$ expressing cells to allow direct comparison to the Brunstein et al study of clinical grade expanded Tregs (derived from antibody-nanobead selection) [24]. In regard to functional marker phenotypes, our expansions were consistent with the Brunstein et al. study; similar low proportions of $41 \mathrm{BB}^{+}$and $\mathrm{OX}^{+} \mathrm{O}^{+}$ 
cells were observed in the expanded Treg cultures. Both of these markers have been associated with inhibition of the suppressive function of Tregs [36, 37]. Our expanded Treg cultures did, however, contain higher proportions of CD62L $\mathrm{L}^{+}$cells than the Brunstein et al. study [24] (median 99.9\% compared to $45 \%$ cells). In the Brunstein et al. study, CD62L expression was used as an indicator of the presence of naïve T cells. A more complete measure of naïve T cells and Tregs, though, can be garnered from the proportion of $C D 62 L^{\text {hi }} C C R 7^{\text {hi }}$ cells [31]. The proportion of $C D 62 L^{\text {hi }} C C R 7^{\text {hi }}$ cells in the our expanded Treg cultures was only median $59 \%$. Thus, the differences between our two studies might simply be due to artefacts of different antibody staining.

We found that the chemokine receptor profile of our expanded Tregs was also highly comparable to that described by Brunstein et al., being predominantly Th2-like (median 61\%). It should be noted that in this chemokine receptor characterisation, Th1 and Th2-like were defined as $\mathrm{CXCR}^{+}$and $\mathrm{CXCR}^{-}{ }^{-} \mathrm{CCR}^{-}$ respectively and loss of CXCR3 expression by Th1 cells has been associated with cellular exhaustion (reviewed [35]). It is unlikely, however, that these are exhausted Th1-like cells since, as previously described, no other exhaustion markers were evident. In summary, our expanded streptamer selected CB Tregs are highly comparable to expanded cultures of conventionally selected Tregs described by Brunstein et al [24].

\section{Conclusions}

The streptamer technology offers an attractive solution for the isolation of Treg cells from cryopreserved cord blood for clinical application. This technology yields a product free of the selecting moiety ("untouched") and uniquely, permits sequential positive selections without flow sorting. This provides improved purity over magnetic bead selection and only slightly lower purity to FACS. Perhaps more importantly, this purity was achieved with cryopreserved starting material, and represents isolation from a readily available source (banked, cryopreserved CB units). The isolated cells could be expanded to at least 300 -fold in a three-week culture period, resulting in a highly suppressive cell population. These expansions are comparable to those previously reported with conventionally isolated CB Tregs in that they retained Treg purity and show low indications of loss of identity or exhaustion. Our study also indicates that clinically relevant doses of Tregs is achievable from frozen CB units using this selection and expansion method. Streptamers thus have the potential (external magnet with closed system and reagent costs only) to be a more cost-effective approach than clinical grade column or sorting based methods.

\section{Materials And Methods}

\section{Peripheral blood and cord blood samples}

All CB samples were obtained with prior consent and ethical committee approval from the Anthony Nolan Cord Blood bank (Research Ethics Committee reference 10/H0405/27). Informed written consent was obtained from pregnant mothers (CB units) and healthy volunteers (PB samples). 


\section{Treg isolation using streptamers}

Treg isolations were performed using a streptamer (JUNO cell therapeutics $\mathrm{GmbH}$, Munich, Germany) based Treg isolation protocol (SUP Fig.2). Using a modification of the method described by Rodriguez et al. [38], cryopreserved CB was thawed in a Dextran thaw mix (10\% Dextran 40 (Sigma-Aldrich, Dorset, UK), $5 \mathrm{mM} \mathrm{MgCL}_{2}$ (VWR international, Poole, UK), 0.64\% Tri-Sodium Citrate (Sigma-Aldrich), $1000 \mathrm{IU} / \mathrm{ml}$ DNAse-1 (Merk Millipore, Watford, UK), 1\% Human serum Albumin (HSA, Sigma-Aldrich, Dorset, UK) in Phosphate buffered saline (PBS; Lonza,Basel, Switzerland). The CB unit was thawed by repeated, brief ( 5s), immersion in a $37^{\circ} \mathrm{C}$ water bath until the unit was semi-frozen, followed by mixing with equal volume of chilled $\left(4^{\circ} \mathrm{C}\right)$ Dextran thaw mix. Isolations were performed in an enclosed bag-based system (SUP Fig.3). For single-step isolations, the thawed unit was injected into the incubation bag followed by pre-prepared anti-CD25 streptamers (SUP Fig.3). Anti-CD25 streptamers were prepared by incubating antiCD25-Fab and Strep-Tactin microbeads for 16 hours at $4^{\circ} \mathrm{C}$. For every $1 \times 10^{8} \mathrm{TNC}$ (total nucleated cell) in the thawed CB unit, $8 \mu \mathrm{L}$ anti-CD25-Fab (JUNO and IBA solutions, Gottingen, Germany), $75 \mu \mathrm{L}$ StrepTactin micro-beads (JUNO/IBA-solutions) were incubated in final volume of $200 \mu \mathrm{L} 1 \% \mathrm{HSA}$ (HSA in Composol (Fresenius transfusions, Friedberg, Germany) or Storage Solution for Platelets (SSP; Macopharma, Mouvaux, France)). TNC was assessed as described previously [39]. The thawed CB was mixed and incubated with anti-CD25 streptamer at $4^{\circ} \mathrm{C}$ for 30 mins. Labelled cells were collected by placing the incubation bag on a DynaMag CTS magnet (ThermoFisher, Leicestershire, UK) for 1-2 mins and draining into a collection bag. The cell-streptamer complex was washed once by gravity feed of chilled $1 \%$ HSA into the incubation bag followed by cell collection on the magnet. Cell clumps, caused by denatured DNA released by dying cells post-thaw, were resolved by injecting $20 \mathrm{~mL}$ of $1 \% \mathrm{HSA}, 1 \times 10^{6}$ $\mathrm{IU} / \mathrm{ml}$ DNAse-1 and incubating for 10 mins RT (room temperature) before collecting the cells. Following two more washes, the streptamers were dissociated from the selected cells by injecting $30 \mathrm{~mL}$ of $2 \mathrm{mM} \mathrm{D-}$ biotin (in RT 1\%HSA). After incubating for 15 mins at RT and collecting the cells, two more incubations were performed with $0.2 \mathrm{mM}$ D-biotin for 10 mins.

For two-step selections, the same procedure was followed, except that an anti-CD4-streptamer selection was performed first. Anti-CD4-Fab-Strep-Tactin complexes were formed by incubation overnight (16hrs) using manufacturer's recommendation/TNC of $40 \mu \mathrm{L}$ anti-CD4-Fab, $150 \mu \mathrm{L}$ Strep-Tactin micro-beads made up to $200 \mu \mathrm{L} 1 \% \mathrm{HSA}$ for every $1 \times 10^{8} \mathrm{TNC}$. The collected cells were then counted and an anti-CD25streptmer selection performed. Anti-CD25-Fab-Strep-Tactin complexes were formed by incubating, for 45 mins $4^{\circ} \mathrm{C}, 2.7 \mu \mathrm{L}$ anti-CD25-Fab, $75 \mu \mathrm{L}$ Strep-Tactin micro-beads made up to $200 \mu \mathrm{L} 1 \% \mathrm{HSA}$ for every $1 \times 10^{8}$ calculated TNC. The calculated TNC was derived from the recovered CD $4^{+}$cell count (calculated TNC $=(100 / 13.9) \times$ the $C D 4^{+}$cell count, based on the average $13.9 \%$ efficiency of selection, that was observed during optimisation of the method).

\section{Characterisation of isolated Tregs}


For flow cytometry of surface antigens, cells were collected with a $550 \mathrm{~g}, 4$ mins centrifugation at $4^{\circ} \mathrm{C}$ and stained with fluorescent conjugated antibodies for 10 mins at $4^{\circ} \mathrm{C}$ in $2.5 \% \mathrm{FBS} /$ phosphate buffered saline (PBS; Lonza, Basel, Switzerland). For intranuclear antigens, the cells were fixed and permeabilised using the FOXP3 staining buffer set (eBioscience, ThermoFisher, Leicestershire, UK) in accordance with the manufacturer's instructions. Tregs were classified as live (DAPI ${ }^{-}$) $\mathrm{CD} 3^{+} \mathrm{CD} 4^{+} \mathrm{CD} 25^{+} \mathrm{CD} 127^{\text {low }}$ (SUP Fig. $4 A$ ); using a separate panel $C D 4^{+} \mathrm{CD} 25^{+} \mathrm{CD} 127^{\text {low }}$ cells were verified as FOXP3 ${ }^{+}$(SUP Fig. 4B). Single-step selections were assessed with panels 1 and 2, whilst two-step selections were assessed with panels 3 and 4 (S1 Table). The cells were acquired on a four laser BD Fortessa (BD Biosciences) and analysed using BD FACS Diva and FlowJo flow cytometry software. Following characterisation of the starting CB unit and isolated cells, the percentage efficiency of selection was calculated as: Efficiency = (number of live $\mathrm{CD} 3^{+} \mathrm{CD} 4^{+} \mathrm{CD} 25^{+} \mathrm{CD} 127^{\text {low }}$ cells in isolated cell fraction/ number of live $\mathrm{CD} 3^{+} \mathrm{CD} 4^{+} \mathrm{CD} 25^{+} \mathrm{CD} 127^{\text {low }}$ cells in starting $\mathrm{CB}$ unit) $\times 100$. The cell yield was calculated as a proportion of the TNC of the starting $\mathrm{CB}$ unit; \%yield = (number of cells isolated/starting TNC) x100.

\section{Suppression assay}

Suppressive function of expanded Tregs was assessed, as described by Stemberger et al. [23], through the suppression of proliferation of target adult PB CD $4^{+}$effector cells, using a CFSE dilution assay. CD $4^{+}$ target cells and $\mathrm{CD}^{-}$feeder cells were isolated, from the same adult donor, from peripheral blood mononuclear cells (PBMC) in accordance with the manufacturer's instructions (CD4 and CD2 microbead kit, Miltenyi Biotec, Woking, UK). Target CD $4^{+}$cells were labelled with $1 \mu \mathrm{M}$ CFSE (CellTrace ${ }^{\text {TM }}$ CFSE Cell Proliferation Kit; Thermo Fisher) for 8 mins at RT in the presence of 5\% FBS/PBS, and the reaction stopped by addition of $10 \mathrm{X}$ volume of chilled $10 \%$ FBS/PBS [40]. Labelled CD $4^{+}$target cells $\left(2 \times 10^{4}\right.$ cells) were incubated at $37^{\circ} \mathrm{C}, 5 \% \mathrm{CO}_{2}$ with Tregs at ratios $2: 1,1: 1,1: 2$ and $1: 4$ Tregs to $\mathrm{CD} 4^{+}$cells $\left(4 \times 10^{4}\right.$, $2 \times 10^{4}, 1 \times 10^{4}$ and $5 \times 10^{3}$ Tregs respectively) along with $1 \times 10^{5}$ irradiated (30 Gy) CD2 ${ }^{-}$cells in 96 ' $\mathrm{u}$ bottom' well plates and complete media (20\% FBS, RPMI 1640 (Gibco, ThermoFisher), 10\% Penicillin/streptomycin (Corning, ThermoFisher)). Proliferation was initiated with the addition of $0.1 \mu \mathrm{g} / \mathrm{mL}$ anti-CD3 antibody (BD Biosciences; OKT3). After five days the cells were collected by centrifugation (550g 4 mins $4^{\circ} \mathrm{C}$ ) and stained with anti-CD4-APC (BD Pharmingen; RPA-TA) for 10 mins at $4^{\circ} \mathrm{C}$ in $2.5 \% \mathrm{FBS} / \mathrm{PBS}$. The proportion of labelled CD4+ cells that proliferated was calculated using the Flowjo proliferation model of CFSE dilution in dividing cells. The percentage suppression $=[(\%$ proliferation of labelled CD $4^{+}$cells in the absence of Tregs $-\%$ proliferation of labelled $\mathrm{CD} 4^{+}$cells with Tregs present)/\% proliferation of labelled CD $4^{+}$cells in the absence of Tregs] $\times 100$.

\section{Expansion of streptamer selected Tregs and effector T cells}

Cell expansion was carried out based on the protocol described in Brunstein et al.[10]. $1 \times 10^{5}$ streptamer isolated Tregs or the $\mathrm{CD} 4^{+} \mathrm{CD} 25^{-}$fraction (effector T cells) from the same cord blood unit, were seeded into 96 'flat bottom' well plates in X-Vivo 15 (Lonza) media supplemented with 10\% AB serum and 2 $\mathrm{mg} / \mathrm{mL} \mathrm{N}$-acetylcysteine. Anti-CD3/28 dynabeads (Human T-activator, Gibco life technologies, 
ThermoFisher) were added at a ratio of $1: 3$, and $1000 \mathrm{lU} / \mathrm{ml} \mathrm{IL}-2$ to a final culture volume of $100 \mu \mathrm{L} /$ well. The cells were incubated for seven days at $37^{\circ} \mathrm{C}, 5 \% \mathrm{CO}_{2}$, feeding on day three and five with fresh IL-2, splitting to maintain a cell density of $\sim 1 \times 10^{5}$ cells/well. On day seven, the cells were harvested, and residual beads removed by passing over a DynaMag (ThermoFisher). The cells were re-seeded at $1 \times 10^{5}$ cells/well and fresh beads applied. The cells were then cultured as before, feeding every two to three days and splitting as required.

\section{Phenotypic characterisation}

Expanded cells were phenotyped by flow cytometry using the antibody panels shown in S2 Table, and protocol above. Viability was assessed with the fixable viability dye eFluro 506 (eBiosciences), and intranuclear staining was carried out following fixation and permeabilization with Fixation/Permeabilization solution (eBiosciences). \% of cells for each population are expressed as the median with ranges.

\section{FOXP3 ${ }^{+}$cell enumeration by methylation status specific quantitative PCR}

Genomic DNA was extracted from expanded Treg and effector T cell cultures using a QIAmp DNA blood mini Kit (Qiagen, Manchester, UK). Natural Treg cell enumeration using methylation specific quantitative polymerase chain reaction (MS-qPCR) was performed as described by Duggleby et al [32]. In brief, genomic DNA was bisulphite converted using the EZ DNA methylation-Gold Kit (Zymo research, Cambridge Bioscience, Cambridge, UK). Real time quantitative PCR was then performed using primers and MGB TaqMan probes (AB applied biosystems, ThermoFisher) specific for the methylated and demethylated sequence of the Treg-specific demethylated region (TSDR) of FOXP3, on a TaqMan Viia 7 348-well block real-time PCR system (Thermofisher), running for 50 cycles. Methylation and demethylation specific reactions were compared to a standard curve of 3-30,000 copies (standards provided by Oxford NHSBT) using the online ThermoFisher applied biosystems tools https://apps.thermofisher.com/apps/spa/. The proportion of Treg and non-Treg cells present in the samples was determined based on the number of methylated and demethylated TSDR copies calculated and after allowing for the sex of the donor as described previously [32].

\section{Statistical Analysis}

Statistical analysis was performed on Graphpad Prism v.7 (Prism, GraphPad Software, La Jolla, CA) using the tests stated within the text.

\section{Abbreviations}

$\mathrm{CB}$; umbilical cord blood, FACS; fluorescent activated cell sorting, GMP; good manufacturing practice, GvHD; graft-versus-host disease, GvT; graft-versus-tumour, HCT; haematopoietic stem cell transplantation, HSA; Human serum Albumin, MS-qPCR; methylation specific quantitative polymerase chain reaction, PB; peripheral blood, PBMC; peripheral blood mononuclear cells, PBS; Phosphate buffered 
saline, RT; room temperature, SSP; Storage Solution for Platelets, TNC; total nucleated cell, Tregs; T regulatory cells, TSDR; Treg-specific demethylated region.

\section{Declarations}

\section{Ethics}

All CB samples were obtained with prior consent and ethical committee approval from the Anthony Nolan Cord Blood bank (Research Ethics Committee reference 10/H0405/27). Informed written consent was obtained from pregnant mothers (CB units) and healthy volunteers (PB samples).

\section{Consent for publication}

Not applicable

\section{Availability of data}

Where possible the raw data are supplied as addition files. Examples of flow cytometry data and analysis, along with the machine settings can be found at https:// flowrepository.org ID: FR-FCM-Z4TH, FR-FCMZ4TN, FR-FCM-Z4TP, FR-FCM-Z4TQ, and FR-FCM-Z4TR.

\section{Competing interests}

Dr Bonig has received personal fees and/or research support from Celgene, Boehringer Ingelheim, Novartis, Medac, Miltenyi Biotec, and Sandoz-Hexal and owns stock in Healthineers, all unrelated to the submitted work. Dr. Germeroth and Dr. Stemberger are employees of Juno Therapeutics GmbH, a Bristol Myers Squibb company. Steptamers are patented with Juno holding the rights to their therapeutic use. Dr. Mielke has received personal fees and non-financial support from Gilead, Miltenyi Biotec, Novartis, Celgene/BMS, KIADIS, and Bellicum, outside the submitted work. Dr. Saudemont was an employee of the Anthony Nolan during data acquisition for this manuscript but is now an employee of GSK. The relevant ICMJE disclosure forms will be submitted with this manuscript. All other authors have no conflicts of interest to disclose.

\section{Funding}

This project was performed under the grant T-Control, funded by the European Union within the 7th Framework Programme under Grant no. 601722

\section{Author contributions}

Richard Duggleby; writing of manuscript (primary author), lead investigator, experimental design, data acquisition, analysis and interpretation. Divya K. Shah; suppression assays, experimental design, review of manuscript. Kathryn E. Strange; methylation status specific quantitative PCR, review of manuscript. Hoi Pat Tsang; experimental design, methylation status specific quantitative PCR, review of manuscript. 
Christian Stemberger; advisory board, experimental design, review of manuscript, Lothar Germeroth; advisory board, experimental design, review of manuscript, Stephan Mielke; advisory board, experimental design, review of manuscript, Halvard Bonig; advisory board, experimental design, review of manuscript, Hermann Einsele; advisory board, experimental design, review of manuscript, David Roberts; experimental design, review of manuscript, Sergio Querol; experimental design, review of manuscript, Alejandro Madrigal; Director of research at Anthony Nolan, advisory board, experimental design, review of manuscript, Aurore Saudemont; Principle Investigator during data acquisition, advisory board, experimental design, review of manuscript, Diana Hernandez; data interpretation, writing of manuscript, Robert Danby; current Principle Investigator, advisory board, experimental design, data interpretation, writing of manuscript.

\section{Acknowledgements}

The authors would like to thank the Anthony Nolan Cell Therapy centre for their assistance. Alasdair McWhinnie, Anthony Nolan Research Institute for his assistance with the Methylation status specific qPCR. Raquel Laza-Briviesca for her assistance with cell isolations.

\section{References}

1. Tang Q, Bluestone JA. Regulatory T-cell therapy in transplantation: moving to the clinic. Cold Spring Harb Perspect Med. 2013 Nov;3(11):1-15. doi: 10.1101/cshperspect.a015552

2. Blazar BR, Murphy WJ, Abedi M. gy Advances in graft-versus-host disease biology and therapy. Nat Rev Immunol. 2012;12(6):443-58. doi: 10.1038/nri3212

3. Cohen JL, Trenado A, Vasey D, Klatzmann D, Salomon BL. CD4+CD25+ Immunoregulatory T Cells: New Therapeutics for Graft-Versus-Host Disease. J Exp Med. 2002 Aug;196(3):401-6. doi: 10.1084/jem.20020090

4. Hoffmann P, Ermann J, Edinger M, Fathman CG, Strober S. Donor-type CD4(+)CD25(+) regulatory T cells suppress lethal acute graft-versus-host disease after allogeneic bone marrow transplantation. $J$ Exp Med. 2002 Aug 5;196(3):389-99. doi: 10.1084/jem.20020399

5. Taylor PA, Noelle RJ, Blazar BR. CD4(+)CD25(+) immune regulatory cells are required for induction of tolerance to alloantigen via costimulatory blockade. J Exp Med. 2001 Jun 4;193(11):1311-8. doi: 10.1084/jem.193.11.1311

6. Edinger M, Hoffmann P, Ermann J, Drago K, Fathman G, Strober S. CD4 + CD25 + regulatory T cells preserve graft-versus- tumor activity while inhibiting graft-versus-host disease after bone marrow transplantation. Nat Med. 2003;9(9):1144-50. doi: 10.1038/nm915

7. Cheraï M, Hamel Y, Baillou C, Touil S, Guillot-Delost M, Charlotte F, et al. Generation of Human Alloantigen-Specific Regulatory T Cells Under Good Manufacturing Practice-Compliant Conditions for Cell Therapy. Cell Transplant. 2015;24(12):2527-40. doi: 10.3727/096368914X683566

8. Duggleby R, Danby RD, Madrigal JA, Saudemont A. Clinical Grade Regulatory CD4+T Cells (Tregs): Moving Toward Cellular-Based Immunomodulatory Therapies. Front Immunol. 2018 Feb 
13;9(February):252. doi: 10.3389/fimmu.2018.00252

9. MacDonald KN, Piret JM, Levings MK. Methods to manufacture regulatory T cells for cell therapy. Clin Exp Immunol. 2019;197(1):52-63. doi: 10.1111/cei.13297

10. Brunstein CG, Miller JS, Cao Q, McKenna DH, Hippen KL, Curtsinger J, et al. Infusion of ex vivo expanded $T$ regulatory cells in adults transplanted with umbilical cord blood: safety profile and detection kinetics. Blood. 2011 Jan 20;117(3):1061-70. doi: 10.1182/blood-2010-07-293795

11. Valmori D, Merlo A, Souleimanian NE, Hesdorffer CS, Ayyoub M. A peripheral circulating compartment of natural naive CD4 Tregs. J Clin Invest. 2005 Jul;115(7):1953-62. doi: $10.1172 / \mathrm{JCl} 23963$

12. Santner-Nanan B, Seddiki N, Zhu E, Quent V, Kelleher A, Fazekas de St Groth B, et al. Accelerated agedependent transition of human regulatory $T$ cells to effector memory phenotype. Int Immunol. 2008 Mar;20(3):375-83. doi: 10.1093/intimm/dxm151

13. Fujimaki W, Takahashi N, Ohnuma K, Nagatsu M, Kurosawa H, Yoshida S, et al. Comparative Study of Regulatory T Cell Function of Human CD25+CD4+ T Cells from Thymocytes, Cord Blood, and Adult Peripheral Blood. Clin Dev Immunol. 2008;2008:1-13. doi: 10.1155/2008/305859

14. Miyara M, Yoshioka Y, Kitoh A, Shima T, Wing K, Niwa A, et al. Functional delineation and differentiation dynamics of human CD4+ T cells expressing the FoxP3 transcription factor. Immunity. 2009 Jun 19;30(6):899-911. doi: 10.1016/j.immuni.2009.03.019

15. Hoffmann P, Eder R, Boeld TJ, Doser K, Piseshka B, Andreesen R, et al. Only the CD45RA+ subpopulation of $C D 4+C D 25$ high $T$ cells gives rise to homogeneous regulatory T-cell lines upon in vitro expansion. Blood. 2006 Dec 15;108(13):4260-7. doi: 10.1182/blood-2006-06-027409

16. Mohr A, Malhotra R, Mayer G, Gorochov G, Miyara M. Human FOXP3+ T regulatory cell heterogeneity. Clin TransI Immunol. 2018;7(1):e1005. doi: 10.1002/cti2.1005

17. Seay HR, Putnam AL, Cserny J, Posgai AL, Rosenau EH, Wingard JR, et al. Expansion of Human Tregs from Cryopreserved Umbilical Cord Blood for GMP-Compliant Autologous Adoptive Cell Transfer Therapy. Mol Ther Methods Clin Dev. 2017 Mar 17;4(March):178-91. doi: 10.1016/j.omtm.2016.12.003

18. Hoffmann P, Boeld TJ, Eder R, Albrecht J, Doser K, Piseshka B, et al. Isolation of CD4+CD25+ regulatory T cells for clinical trials. Biol Blood Marrow Transplant. 2006 Mar;12(3):267-74. doi: 10.1016/j.bbmt.2006.01.005

19. Theil A, Tuve S, Oelschlägel U, Maiwald A, Döhler D, Oßmann D, et al. Adoptive transfer of allogeneic regulatory T cells into patients with chronic graft-versus-host disease. Cytotherapy. 2015;17(4):47386. doi: $10.1016 /$ j.jcyt.2014.11.005

20. Zhang W, Smythe J, Frith E, Belfield H, Clarke S, Watt SM, et al. An innovative method to generate a Good Manufacturing Practice-ready regulatory T-cell product from non-mobilized leukapheresis donors. Cytotherapy. 2015;17(9):1268-79. doi: 10.1016/j.jcyt.2015.05.015

21. Patel P, Mahmud D, Park Y, Yoshinaga K, Mahmud N, Rondelli D. Clinical grade isolation of regulatory T cells from G-CSF mobilized peripheral blood improves with initial depletion of monocytes. Am J 
Blood Res. 2015;5(2):79-85.

22. Peters JH, Preijers FW, Woestenenk R, Hilbrands LB, Koenen HJPM., Joosten I. Clinical grade Treg: GMP isolation, improvement of purity by CD127 Depletion, Treg expansion, and Treg cryopreservation. Unutmaz D, editor. PLoS One. 2008 Sep;3(9):e3161. doi: 10.1371/journal.pone.0003161

23. Stemberger C, Dreher S, Tschulik C, Piossek C, Bet J, Yamamoto TN, et al. Novel serial positive enrichment technology enables clinical multiparameter cell sorting. PLoS One. 2012 Jan;7(4):e35798. doi: 10.1371/journal.pone.0035798

24. Brunstein CG, Miller JS, McKenna DH, Hippen KL, DeFor TE, Sumstad D, et al. Umbilical cord bloodderived T regulatory cells to prevent GVHD: kinetics, toxicity profile, and clinical effect. Blood. 2016 Feb 25;127(8):1044-51. doi: 10.1182/blood-2015-06-653667

25. Baron U, Floess S, Wieczorek G, Baumann K, Grützkau A, Dong J, et al. DNA demethylation in the human FOXP3 locus discriminates regulatory T cells from activated FOXP3(+) conventional T cells. Eur J Immunol. 2007 Sep;37(9):2378-89. doi: 10.1002/eji.200737594

26. Seddiki N, Santner-Nanan B, Martinson J, Zaunders J, Sasson S, Landay A, et al. Expression of interleukin (IL)-2 and IL-7 receptors discriminates between human regulatory and activated $T$ cells. J Exp Med. 2006 Jul;203(7):1693-700. doi: 10.1084/jem.20060468

27. Chen X, Oppenheim JJ. Resolving the identity myth: key markers of functional CD4+FoxP3+ regulatory T cells. Int Immunopharmacol. 2011 Oct;11(10):1489-96. doi:

10.1016/j.intimp.2011.05.018

28. Thornton AM, Korty PE, Tran DQ, Wohlfert EA, Murray PE, Belkaid Y, et al. Expression of Helios, an Ikaros transcription factor family member, differentiates thymic-derived from peripherally induced Foxp3+ T regulatory cells. J Immunol. 2010;184(7):3433-41. doi: 10.4049/jimmunol.0904028

29. Matos TR, Hirakawa M, Alho AC, Neleman L, Graca L, Ritz J. Maturation and Phenotypic Heterogeneity of Human CD4+ Regulatory T Cells From Birth to Adulthood and After Allogeneic Stem Cell Transplantation. Front Immunol. 2021;11(January):1-10. doi: 10.3389/fimmu.2020.570550

30. Zou L, Barnett B, Safah H, Larussa VF, Evdemon-Hogan M, Mottram P, et al. Bone marrow is a reservoir for CD4+CD25+ regulatory T cells that traffic through CXCL12/CXCR4 signals. Cancer Res. 2004 Nov 15;64(22):8451-5. doi: 10.1158/0008-5472.CAN-04-1987

31. Lim HW, Broxmeyer HE, Kim CH. Regulation of trafficking receptor expression in human forkhead box P3+ regulatory T cells. J Immunol. 2006 Jul 15;177(2):840-51. doi: 10.4049/jimmunol.177.2.840

32. Duggleby RC, Tsang HP, Strange K, McWhinnie A, Lamikanra AA, Roberts DJ, et al. Enumerating regulatory $T$ cells in cryopreserved umbilical cord blood samples using FOXP3 methylation specific quantitative PCR. PLoS One. 2020;15(10):e0240190. doi: 10.1371/journal.pone.0240190

33. Floess S, Freyer J, Siewert C, Baron U, Olek S, Polansky J, et al. Epigenetic control of the foxp3 locus in regulatory T cells. PLoS Biol. 2007 Feb;5(2):e38. doi: 10.1371/journal.pbio.0050038

34. Lowther DE, Goods BA, Lucca LE, Lerner BA, Raddassi K, van Dijk D, et al. PD-1 marks dysfunctional regulatory T cells in malignant gliomas. JCI insight. 2016 Apr 21;1(5):1-15. doi: 
10.1172/jci.insight.85935

35. Wherry EJ, Kurachi M. Molecular and cellular insights into T cell exhaustion. Nat Rev Immunol. 2015 Aug;15(8):486-99. doi: 10.1038/nri3862

36. Choi BK, Bae JS, Choi EM, Kang WJ, Sakaguchi S, Vinay DS, et al. 4-1BB-dependent inhibition of immunosuppression by activated CD4 + CD25 + T cells. J Leukoc Biol. 2004;75(5):785-91. doi: 10.1189/jlb.1003491

37. Voo KS, Bover L, Harline ML, Vien LT, Facchinetti V, Arima K, et al. Antibodies targeting human OX40 expand effector T cells and block inducible and natural regulatory T cell function. J Immunol. 2013 Oct 1;191(7):3641-50. doi: 10.4049/jimmunol.1202752

38. Rodríguez L, Azqueta C, Azzalin S, García J, Querol S. Washing of cord blood grafts after thawing: high cell recovery using an automated and closed system. Vox Sang. 2004 Oct;87(3):165-72. doi: 10.1111/j.1423-0410.2004.00550.x

39. Duggleby RC, Madrigal JAA. Methods of detection of immune reconstitution and T regulatory cells by flow cytometry. In: Beksaç M, editor. Bone Marrow and Stem Cell Transplantation. New York, NY: Springer New York; 2014. p. 159-86. doi: 10.1007/978-1-4614-9437-9_10

40. Quah BJC, Warren HS, Parish CR. Monitoring lymphocyte proliferation in vitro and in vivo with the intracellular fluorescent dye carboxyfluorescein diacetate succinimidyl ester. Nat Protoc. 2007;2(9):2049-56. doi: 10.1038/nprot.2007.296

\section{Figures}
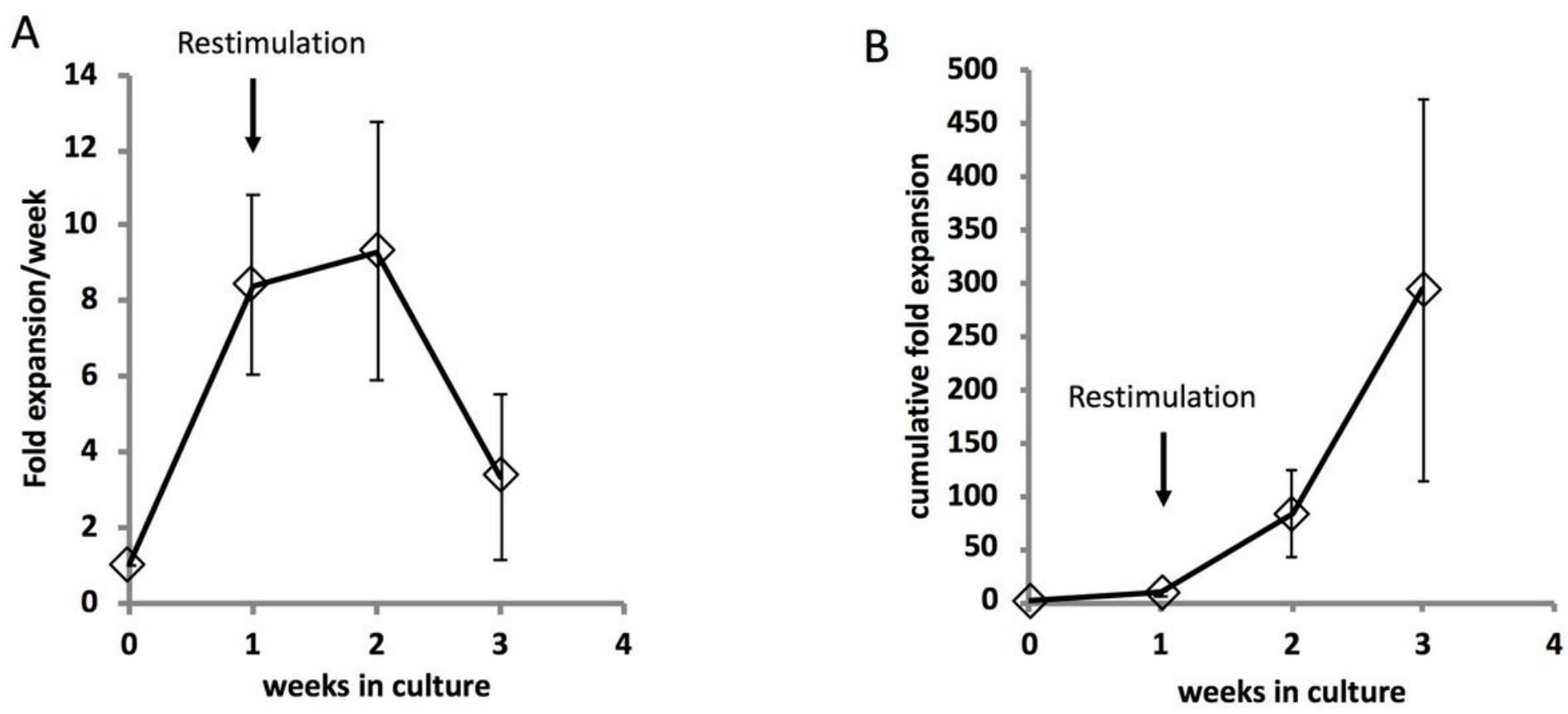

Figure 1 
Growth rate and cumulative fold expansion of streptamer selected Tregs cultured with anti-CD3/28

Dynabeads. Two-step (CD4 and CD25 streptamer) selected cells were expanded with anti-CD3/28 Dynabeads ( $n=8)$ and $1000 \mathrm{IU} / \mathrm{mL} \mathrm{IL}-2$. (A) fold expansion observed each week in culture, (B) cumulative fold expansion. Restimulation occurred on day 7 , as indicated.

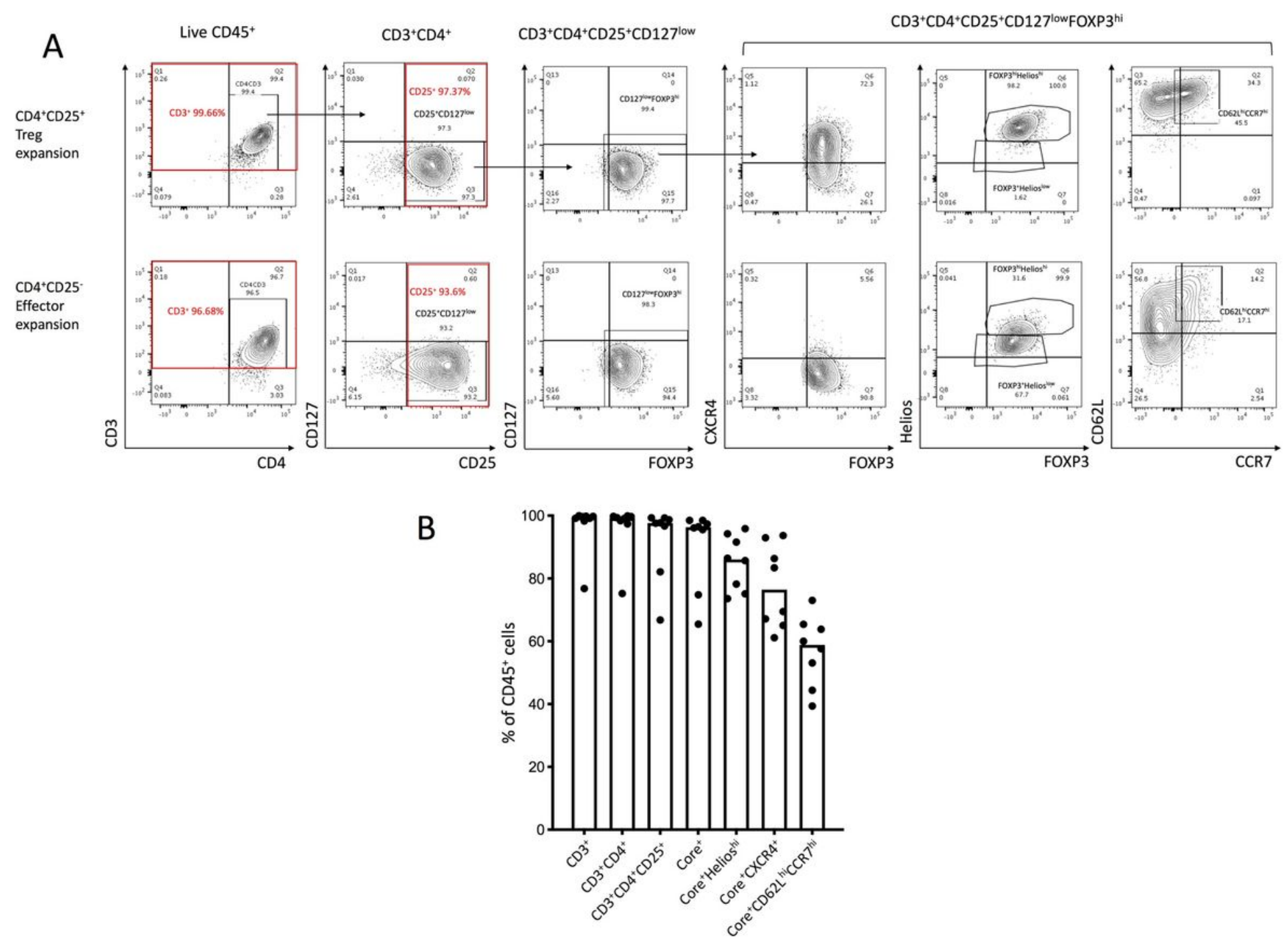

Figure 2

Phenotypic characterisation of Treg cultures post expansion. A) example flow cytometric characterisation of expanded cells. Successive gating of live $\mathrm{CD} 45^{+}$(eFluro 506-) cells for the indicated subpopulations after three weeks of expansion with two-step streptamer selected Tregs or the CD4 ${ }^{+}$CD25- (effector) fraction from the same selection. Data shown in the first three sets of plots and when gating for $\mathrm{CXCR} 4^{+}$ cells are with antibody panel 2 (S2 Table) whilst $\mathrm{Helios}^{+}$and CD62 $\mathrm{L}^{\text {hi }} \mathrm{CCR} 7^{\text {hi }}$ cells are defined using panel 1 on the same cells. B) the gated subpopulations from (A) as a proportion of Live $\mathrm{CD} 45^{+}$cells. The core Treg phenotype of $\mathrm{CD} 3^{+} \mathrm{CD} 4^{+} \mathrm{CD} 25^{+} \mathrm{CD} 127^{\text {low }} \mathrm{FOXP} 3^{\text {hi }}$ cells, before applying further sub-gating, has been abbreviated to Core ${ }^{+}$. No significant difference was found between proportions of $\mathrm{CD} 3^{+}, \mathrm{CD} 4^{+} \mathrm{CD} 3^{+}$, $\mathrm{CD} 3^{+} \mathrm{CD} 4^{+} \mathrm{CD} 25^{+}$and $\mathrm{Core}^{+}$cells using either panel 1 or panel 2. Bars indicated medians. 


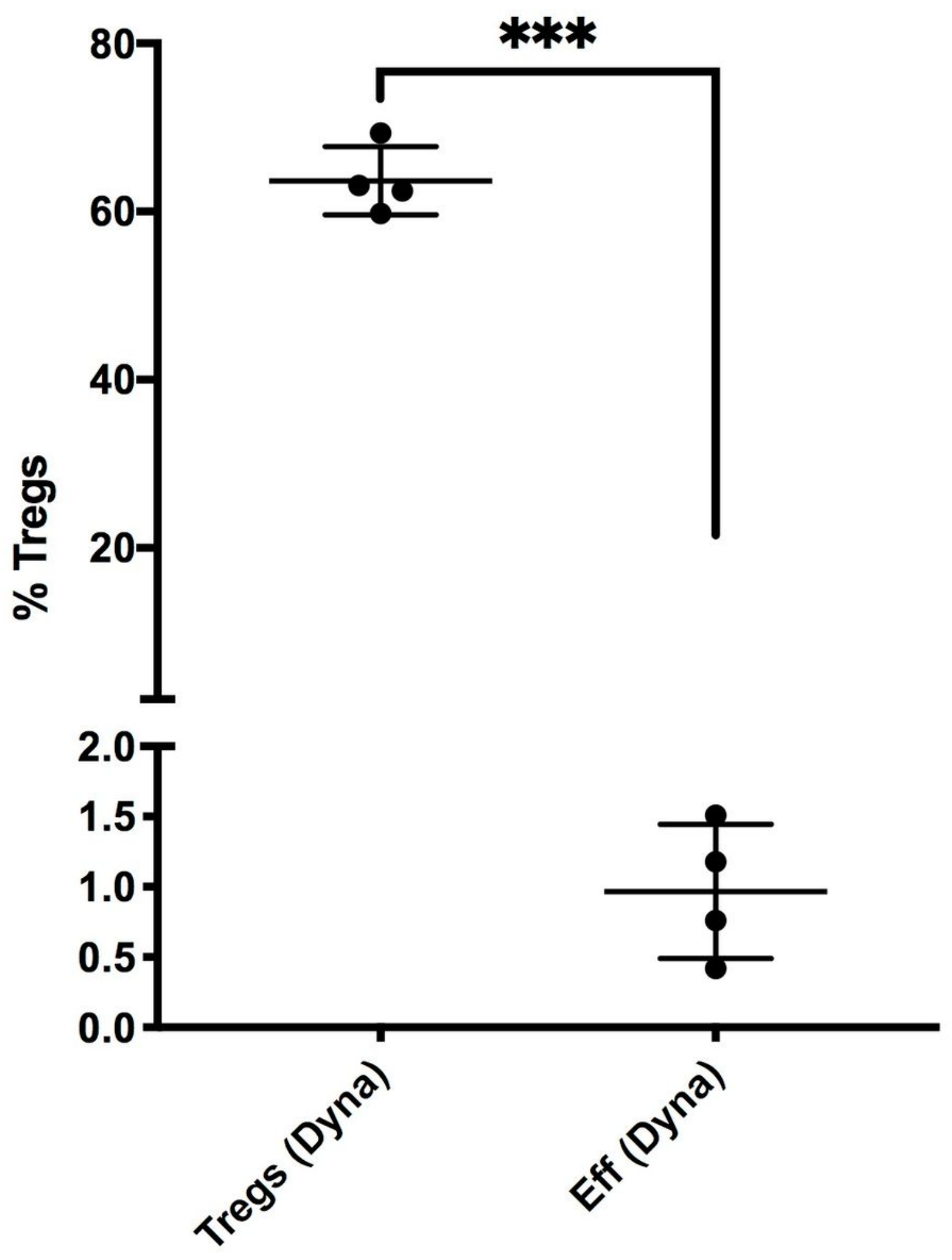

Figure 3

DNA based enumeration of Tregs in expanded Treg and effector cultures. DNA was extracted from each expanded culture between week 3-4 of culture. The proportion of demethylated FOXP3 TSDR from natural Tregs was then calculated using a MS-qPCR assay. Shown is the calculated proportion of Tregs based on methylation status of DNA from expanded two-step streptamer selected Tregs or expanded CD $4^{+} \mathrm{CD} 25^{-}$ 
fraction (effectors) from the same selection $(n=4)$. Shown are mean \pm standard deviation with the results of paired t-tests. ${ }^{\star \star \star}=p \leq 0.001$.

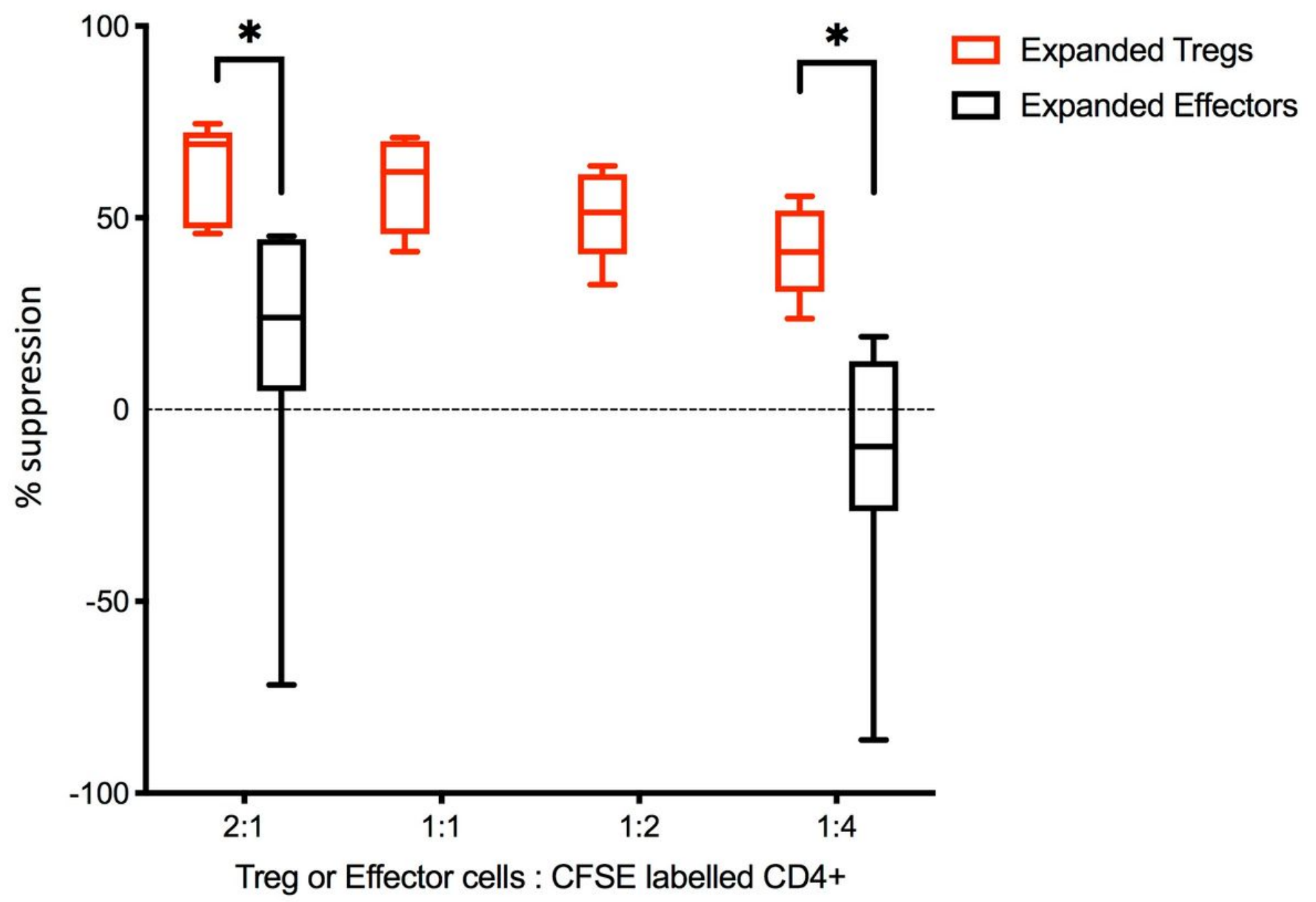

Figure 4

Suppression observed with expanded Tregs or effectors. Percentage suppression of proliferation of CFSE labelled PB CD4 ${ }^{+}$cells stimulated with anti-CD3 (OKT3) antibody. Shown is suppression by expanded Tregs or expanded effector $T$ cells cultured for two weeks, at the cells to target cell ratios indicated. Box and whiskers with medians. ${ }^{*}=p \leq 0.05$ by Wilcoxon paired t-test. 
A

Exhaustion markers

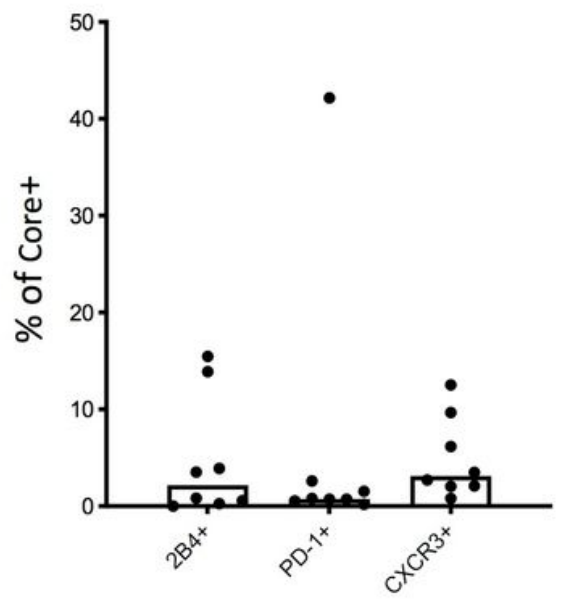

B

Loss of function markers

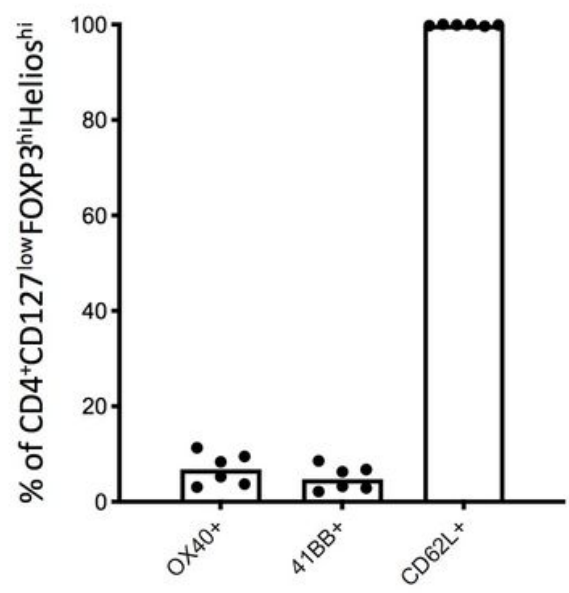

C

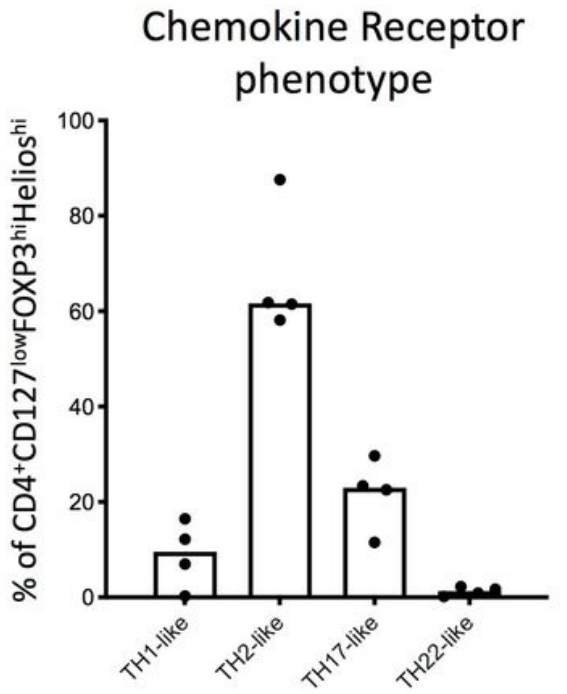

Figure 5

Extended phenotype of expanded Tregs.

Flow cytometry assessment of two-step streptamer selected Tregs after three weeks of expansion. A) Proportions of live (eFluro $506^{-}$) cells expressing the core Treg phenotype $\left(\mathrm{CD}^{+} \mathrm{CD} 4^{+} \mathrm{CD} 25^{+} \mathrm{CD} 127^{\text {low }} \mathrm{FOXP} 3^{\text {hi }}\right.$ ) positive for 2B4, PD1 and CXCR3. Data from antibody panel 2 (S2 Table) is shown for $2 \mathrm{~B} 4^{+}$cells and panel 3 for $\mathrm{PD}-1^{+}$and $\mathrm{CXCR} 3$

${ }^{+}$cells. No significant difference in the proportions of cells expressing the core phenotype were detected using the two panels. (B) Proportions of live CD $4^{+} C D 127^{\text {low }} F O X P 3^{\text {hi }} H e l i o s^{\text {hi }}$ cells positive for OX40, 41BB and CD62L. (C) Proportions of live CD $4^{+}$CD127 ${ }^{\text {low } F O X P 3 ~}{ }^{\text {hi }}{ }^{\text {Helios }}{ }^{\text {hi }}$ cells with a Th1, Th2, Th17 or Th22like chemokine receptor phenotype.

Bars indicated medians

\section{Supplementary Files}

This is a list of supplementary files associated with this preprint. Click to download.

- Table1rawdata.xlsx

- RawdataFig2.xlsx

- RawdataFigure1and4.xlsx

- SUPFIG1.tif

- SUPFIG2.tif

- SUPFIG3.tif

- SUPFIG4.tif 
- SupplementaryTables.docx

Page 24/24 